\title{
PENGARUH EDUKASI PENGATURAN DIET TERHADAP PERILAKU PENGELOLAAN DIET PADA PENDERITA DIABETES MELITUS DI KELURAHAN AGROWISATA KECAMATAN RUMBAI KOTA PEKANBARU
}

\author{
Angga Arfina \\ Program Studi S1 Keperawatan, STIKes Payung Negeri Pekanbaru \\ E-mail : angga_arfina@yahoo.com
}

\begin{abstract}
Diabetes mellitus (DM) is a chronic disease that causes hyperglycemia thereby increasing glucose levels in the blood. One component of management and care that is essential for people with DM is the regulation of diets that can be provided through educational programs. Education a role in helping sufferers improve metabolic control and change their eating behavior. This study aims to determine the effect of dietary education on diet management behavior in patients with diabetes mellitus in Agrowisata Rumbai Pekanbaru. This research is a quantitative descriptive study with a quasi experimental design with pre and postest without control. The research sample was DM patients with 28 people with consecutive sampling technique. Data collection was done by DM diet management behavior questionnaire. Data were analyzed using dependent $\mathrm{T}$ test statistics. The results showed that there was an influence of dietary education education on diet management behavior of DM sufferers $(p=0,000<0.05)$. The results showed that education increased the behavior of respondents in managing the diet from an average of 39.29 to 46.36 . The results of this study can be input for health services to be able to maintain and improve education in DM patients. Education can improve the skills of sufferers to manage diabetes more effectively by regulating a healthy diet so that people with diabetes are expected to be able to prevent complications that can arise.
\end{abstract}

Keywords: Education on diet management, Behavior of diet management, Diabetes mellitus

\begin{abstract}
Abstrak
Diabetes melitus (DM) merupakan salah satu penyakit kronis yang menyebabkan hiperglikemia sehingga meningkatkan kadar glukosa dalam darah. Salah satu komponen penatalaksanaan dan perawatan yang esensial bagi penderita DM adalah dengan pengaturan diet yang dapat diberikan melalui program edukasi. Edukasi berperan membantu penderita meningkatkan pengendalian metabolisme serta mengubah perilaku makan mereka. Penelitian ini bertujuan mengetahui pengaruh edukasi pengaturan diet terhadap perilaku pengelolaan diet pada penderita diabetes melitus di Kelurahan Agrowisata Kecamatan Rumbai Kota Pekanbaru. Penelitian ini merupakan penelitian deskriptif kuantitatif dengan desain quasi eksperiment pre and post test without control. Sampel penelitian adalah penderita DM berjumlah 28 orang dengan teknik consecutive sampling. Pengumpulan data dilakukan dengan kuesioner perilaku pengelolaan diet DM. Data dianalisis menggunakan statistik uji $\mathrm{T}$ dependen. Hasil penelitian menunjukkan ada pengaruh edukasi pengaturan diet terhadap perilaku pengelolaan diet penderita $\mathrm{DM}(\mathrm{p}=0,000<0,05)$. Hasil penelitian menunjukkan bahwa edukasi meningkatkan perilaku responden dalam pengelolaan diet dari ratarata 39,29 menjadi 46,36. Hasil penelitian ini dapat menjadi masukan bagi pelayanan kesehatan untuk dapat mempertahankan dan meningkatkan edukasi pada pasien DM. Edukasi dapat meningkatkan keterampilan penderita mengelola diabetes secara lebih efektif dengan pengaturan diet sehat sehingga diharapkan penderita DM mampu mencegah komplikasi yang dapat muncul.

Kata Kunci: Edukasi pengaturan diet, Perilaku pengelolaan diet, Diabetes melitus
\end{abstract}




\section{PENDAHULUAN}

Saat ini Diabetes melitus (DM) menjadi salah satu prioritas penyakit tidak menular. DM merupakan penyakit bersifat progresif yang terjadi akibat defek sekresi insulin, kerja insulin atau keduanya. Hal ini mengakibatkan terjadinya peningkatan kadar glukosa dalam darah atau disebut juga dengan hiperglikemia. DM dapat dikategorikan dalam berbagai klasifikasi berdasarkan penyebab, perjalanan klinis penyakit serta pengobatannya (Smeltzer, Bare, Hinkle \& Cheever, 2010). Secara umum DM diklasifikasikan menjadi DM Tipe 1, DM Tipe 2, DM Gestasional dan DM Tipe Lain (Black \& Hawks, 2014). Bila DM tidak terkontrol akan menyebabkan kerusakan pada berbagai organ dan komplikasi antara lain kebutaan, serangan jantung, penyakit stroke, gagal ginjal dan amputasi (Sami, et al, 2017).

The International Diabetes Federation (IDF) Atlas (2015) menyatakan pada tahun 2015 terdapat sekitar 415 juta orang dewasa mengalami DM dan diperkirakan pada tahun 2040 akan mengalami peningkatan menjadi 642 juta. Hampir $80 \%$ DM terjadi di negara dengan berpenghasilan rendah dan menengah. Indonesia merupakan salah satu negara yang memiliki populasi DM tertinggi di dunia. Berdasarkan pemeriksaan kadar gula darah pada penduduk usia lebih dari 15 tahun dengan menggunakan kriteria ADA dan konsensus Perkeni 2015 didapatkan prevalensi DM 10,9\% (Riskesdas, 2018).

Jenis pengendalian DM di Indonesia berdasarkan diagnosis dokter didapatkan $80,2 \%$ dengan pengaturan diet, $48,1 \%$ olahraga, $35,7 \%$ alternatif herbal dan masih terdapat $12,8 \%$ penderita yang tidak rutin memeriksakan kadar gula darah. Sementara itu, di Riau masih terdapat 7,9\% kasus DM yang tidak diobati (Riskesdas, 2018). Hal ini menggambarkan bahwa DM merupakan penyakit kronis yang membutuhkan penanganan yang kompleks.

Sebagai penatalaksanaan DM tenaga kesehatan dapat memberikan pendidikan kesehatan yang berkesinambungan. Salah satu komponen penatalaksanaan dan perawatan yang esensial adalah dengan pengaturan diet. Hal ini bertujuan untuk membantu penderita meningkatkan pengendalian metabolisme serta mengubah perilaku makan mereka (Black \& Hawks, 2014).

American Diabetes Association (ADA) merekomendasikan pengaturan diet sebagai salah satu kunci bagi penderita DM untuk mencegah perkembangan penyakit. Konsumsi daging merah, permen dan makanan gorengan yang tinggi berkontribusi pada peningkatan risiko resistensi insulin. Penelitian di Jepang mengungkapkan bahwa peningkatan asupan beras putih dikaitkan juga dengan peningkatan risiko DM (Sami, et al, 2017). Hal ini sesuai dengan penelitian yang dilakukan oleh Valley (dalam Sami, et al, 2017) menyatakan bahwa terdapat hubungan antara konsumsi lemak dengan gangguan toleransi glukosa.

Penelitian Savoca dan Miller (dalam Sami et al, 2017) menyatakan bahwa pemilihan makanan dan perilaku diet penderita DM dipengaruhi oleh pengetahuan yang kuat tentang rekomendasi diet diabetes. Hasil penelitian tersebut terdapat hubungan yang positif antara pengetahuan tentang diet diabetes dan jumlah kebutuhan kalori $(\mathrm{r}=$ $0,27, p<0,05)$. Penelitian ini menyimpulkan bahwa pengetahuan tentang diet diabetes penting dan diperlukan untuk mencapai perilaku diet yang lebih baik. Berdasarkan data Riskesdas (2018) di Riau pengendalian diabetes dengan cara mengatur makanan baru mencapai $77 \%$ dengan persentase tertinggi tingkat pendidikan penderita adalah perguruan tinggi $88,1 \%$.

Berdasarkan berbagai uraian pada latar belakang tersebut, maka peneliti tertarik melakukan penelitian tentang "Pengaruh Edukasi Pengaturan Diet Terhadap Perilaku Pengelolaan Diet Pada Penderita Diabetes Melitus di Kelurahan Agrowisata Kecamatan Rumbai Kota Pekanbaru".

\section{METODE PENELITIAN}

Penelitian ini merupakan penelitian deskriptif kuantitatif dengan desain quasi eksperiment pre and post test without 
control. Sampel dalam penelitian ini adalah penderita DM yang berjumlah 28 orang di Kelurahan Agrowisata Kecamatan Rumbai Kota Pekanbaru. Pengambilan sampel dilakukan dengan metode non probability sampling. Teknik yang dilakukan dalam pemilihan sampel adalah consecutive sampling dengan kriteria inklusi penderita DM yang kooperatif, tinggal bersama keluarga. Penelitian ini dilakukan pada bulan April 2019.

Instrumen yang digunakan dalam penelitian ini adalah kuesioner tentang perilaku pengelolaan diet pada penderita DM. Instrumen tersebut telah dilakukan uji validitas dan reliabilitas pada 28 responden di Kelurahan Maharani Kecamatan Rumbai Kota Pekanbaru. Hasil uji validitas kuesioner didapatkan dengan membandingkan nilai $r$ tabel dan nilai $r$ hitung pada setiap item pertanyaan pada tingkat kemaknaan 5\% (df $=$ n-2).

Hasil yang didapat dari 15 pertanyaan dinyatakan valid dengan $\mathrm{r}$ hitung 0,351 $0,615>\mathrm{r}$ tabel 0,317. Uji reliabilitas kuesioner dilihat dari nilai Cronbach Alpha dengan nilai $\geq 0,6$ dinyatakan reliabel. Hasil perhitungan didapatkan nilai Cronbach Alpha 0,803 , maka semua pertanyaan dalam kuesioner dinyatakan reliabel.

Setelah seluruh data pada penelitian ini terkumpul maka dilakukan analisis data secara univariat dan bivariat. Analisis bivariat dilakukan dengan menggunakan statistik uji $\mathrm{T}$ dependen untuk melihat apakah terdapat pengaruh edukasi terhadap perilaku pengelolaan diet pada penderita DM sebelum dan sesudah diberikan edukasi.

\section{HASIL PENELITIAN}

Berdasarkan hasil penelitian rata-rata usia responden dalam penelitian ini adalah 50,75 tahun dengan standar deviasi (SD) 8,47 . Pada penelitian ini dari 28 responden proporsi jenis kelamin laki-laki yaitu 13 $(46,4 \%)$ orang dan perempuan $15(53,6 \%)$ orang. Tingkat pendidikan rata-rata responden adalah SMA sebanyak 19 (67,9\%) orang dengan status pekerjaan tidak bekerja atau Ibu Rumah Tangga (IRT) sebanyak 13
$(46,4 \%)$ orang dan wiraswasta $8(28,6 \%)$ orang. Sebagian besar responden dengan status menikah sebanyak 19 (67,9\%) dengan lama menderita DM rata-rata kurang dari 6 bulan sebanyak $10(35,7 \%)$ orang dan 6 bulan sampai 1 tahun sebanyak $11(39,3 \%)$ orang.

\section{Pengaruh Edukasi Tentang Pengaturan Diet Diabetes Terhadap Perilaku Pengelolaan Diet Pada Penderita Diabetes Melitus}

Analisis bivariat dilakukan untuk mengetahui pengaruh variabel independen yaitu edukasi pengaturan diet diabetes terhadap variabel dependen yaitu perilaku pengelolaan diet pada penderita diabetes melitus. Analisis dilakukan dengan menggunakan uji $\mathrm{T}$ dependen dengan hasil sebagai berikut:

Tabel 1. Pengaruh Edukasi Tentang Pengaturan Diet Diabetes Terhadap Perilaku Pengelolaan Diet Pada Penderita Diabetes Melitus ( $\mathrm{n}=28)$

\begin{tabular}{lccc}
$\begin{array}{l}\text { Perilaku } \\
\text { Pengelolaan } \\
\text { Diet DM }\end{array}$ & Mean & SD & p value \\
\cline { 1 - 3 } Sebelum & 39,29 & 2,370 & 0.000 \\
\hline Sesudah & 46,36 & 5,445 & \\
\hline
\end{tabular}

Tabel 1 menunjukkan hasil uji statistik pengaruh edukasi pengaturan diet terhadap perilaku pengelolaan diet pada penderita diabetes melitus. Hasil penelitian terlihat bahwa pemberian edukasi meningkatkan perilaku responden dalam pengelolaan diet yaitu dari rata-rata 39,29 sebelum edukasi menjadi 46,36 sesudah diberikan edukasi. Hasil uji $\mathrm{T}$ diperoleh $\mathrm{p}$ value 0,000 artinya secara statistik ada perbedaan yang signifikan perilaku pengelolaan diet antara sebelum dan sesudah pemberian edukasi.

\section{PEMBAHASAN}

Perawatan diabetes bertujuan untuk meningkatkan kemampuan penderita dalam mengontrol kadar glikemik dengan menyeimbangkan asupan makanan terhadap kadar insulin endogen dan atau eksogen. Pada penderita DM Tipe 1, dosis insulin harus disesuaikan agar seimbang dengan 
asupan makanan yang bergizi dan aktivitas fisik. Individu dengan DM Tipe 2 perlu memperhatikan porsi makanan, manajemen berat badan yang dikombinasikan dengan aktivitas fisik sehingga dapat membantu meningkatkan kontrol glikemik(Paswan, et al, 2016).

Manajemen gizi bagi penderita DM dilakukan sebagai upaya untuk memperbaiki atau mempertahankan beberapa hal, antara lain kualitas hidup penderita dan keluarga melalui teknik manajemen yang mencakup seluruh unit keluarga dalam pengambilan keputusan. Selain itu, program manajemen gizi juga bermanfaat bagi kesehatan penderita DM untuk dapat mempertahankan kadar glukosa darah dan lipid sedekat mungkin dengan nilai normal, mencegah komplikasi serta mempertahankan kebutuhan mikro dan makro nutriennya sama dengan orang sehat (Paswan, et al, 2016).

Beberapa perilaku self care yang sangat penting pada penderita DM antara lain mengatur diet yang sehat, melakukan aktivitas fisik, kontrol gula darah, mematuhi program pengobatan, koping yang efektif, perilaku pencegahan risiko serta kemampuan memecahkan masalah yang baik (Shrivastava, Shrivastava \& Ramasamy, 2013). Pada hasil penelitian ini terlihat bahwa pemberian edukasi meningkatkan perilaku responden dalam pengelolaan diet yaitu dari 39,29 sebelum edukasi menjadi 46,36 sesudah diberikan edukasi dengan $p$ value 0,000 . Hal ini artinya secara statistik ada perbedaan yang signifikan antara perilaku pengelolaan diet sebelum dan sesudah pemberian edukasi.

Penelitian ini sesuai dengan penelitian yang dilakukan Muchiri, Gericke dan Rheeder (2016) pada 82 responden tentang pengaruh Nutrition Education (NE) terhadap pengetahuan dan sikap penderita DM Tipe 2 di Moretele Afrika Selatan. Penelitian tersebut dilakukan selama 6 sampai 12 bulan dengan analisis co variance didapatkan hasil pada kelompok intervensi nilai pengetahuan rata-rata adalah $+0,95(\mathrm{p}=0,0333)$ dan sikap $+0,27(\mathrm{p}=0,028)$. Hal ini menyatakan NE secara signifikan meningkatkan pengetahuan dan sikap penderita DM.

Pemberian edukasi sangat efektif memperbaiki hasil klinis dan kualitas hidup penderita DM (Funnel et al, 2012). Nutrisi, terapi dan pengobatan merupakan bagian tak terpisahkan dalam perawatan dan manajemen diri penderita diabetes. Status gizi buruk pada penderita menurunkan kemampuan kontrol glikemik. Terapi nutrisi yang diimbangi dengan manajemen diri diabetes lainnya dapat mengurangi glikemik hemoglobin 1,0 $2,0 \%$. Hal ini akan membantu penderita DM meningkatkan hasil klinis dan metabolismenya. Konsistensi dalam pengaturan jarak dan asupan karbohidrat dalam makanan juga dapat membantu penderita mengontrol kadar gula darah dan berat badan (Sievenpiper, et al, 2018).

Menurut Sievenpiper, et al (2018) intervensi perilaku sehat yang intensif pada orang dengan diabetes dapat menghasilkan perbaikan dalam manajemen berat badan, kebugaran, kontrol glikemik, dan faktor risiko kardiovaskular. Beberapa faktor yang dapat mempengaruhi perilaku pengelolaan diet penderita DM antara lain usia, jenis kelamin, tingkat pendidikan dan lama menderita penyakit. Pada penelitian ini menunjukkan bahwa rata-rata usia responden 50,75 tahun dengan jenis kelamin perempuan $15(53,6 \%)$ orang, tingkat pendidikan ratarata responden adalah SMA sebanyak 19 $(67,9 \%)$ orang dengan lama menderita DM rata-rata kurang dari 6 bulan sebanyak 10 $(35,7 \%)$ orang dan 6 bulan sampai 1 tahun sebanyak $11(39,3 \%)$ orang.

Individu dengan tingkat pendidikan yang tinggi biasanya mempunyai banyak informasi dan pengetahuan tentang kesehatan sehingga mereka cenderung memiliki kesadaran dalam menjaga kesehatannya. Hal ini juga berpengaruh pada mereka yang telah menderita suatu penyakit yang cukup lama. Penderita DM yang telah terdiagnosis lebih awal biasanya lebih mengetahui faktor-faktor apa saja yang akan berpengaruh terhadap perkembangan penyakitnya (Fauzia, Nugroho \& Margawati, 2018). Riskesdas (2018) menyatakan proporsi jenis pengendalian DM 
dengan cara pengaturan makanan pada kelompok usia 45-54 tahun adalah 81,7\%, jenis kelamin perempuan $81,5 \%$ dan tingkat pendidikan SMA $82,2 \%$.

Hal ini didukung oleh penelitian Karaoui, et al (2018) pada 207 penderita DM di Lebanon yang dianalisis dengan linier berganda. Hasil penelitian menyatakan pengetahuan $(B e t a=0,448, \quad p=0,001)$ dan praktik manajemen diri (Beta 0,523, $\mathrm{p}=0,047$ ) diabetes lebih tinggi pada penderita DM dengan tingkat pendidikan perguruan tinggi dibandingkan tingkat pendidikan menengah. Penelitian tersebut juga menyatakan terdapat hubungan yang signifikan antara pengetahuan dan praktik manajemen diri (Beta=0,844, $\mathrm{p}=<0,001$ ). Namun tidak terdapat perbedaan yang signifikan berdasarkan jenis kelamin dan usia terhadap praktik manajemen diri penderita DM.

Penderita diabetes harus didorong untuk memilih pola diet yang selaras dengan nilai, preferensi, dan tujuan perawatan yang memungkinkan mereka mencapai kepatuhan terbesar dalam jangka panjang. Penderita DM yang mendapatkan edukasi yang benar dan berkesinambungan dapat mambatu mereka untuk mengelola perawatan diri akibat penyakitnya . Melalui pemberian program edukasi diharapkan penderita DM mampu mencegah komplikasi yang dapat muncul. Selain itu berpartisipasi dalam program pendidikan kesehatan dapat meningkatkan keterampilan penderita mengelola diabetes secara lebih efektif dengan memeriksa gula darah secara teratur, diet sehat, melakukan aktivitas fisik, minum obat sesuai resep dokter, serta menangani stres akibat diabetes (CDC, 2018).

\section{KESIMPULAN}

Berdasarkan hasil penelitian terdapat pengaruh edukasi pengaturan diet terhadap perilaku pengelolaan diet pada penderita diabetes melitus. Secara statistik ada perbedaan yang signifikan perilaku pengelolaan diet antara sebelum dan sesudah pemberian edukasi.

\section{SARAN}

Hasil penelitian memberikan beberapa saran kepada praktek dan pelayanan keperawatan untuk perlu melakukan program edukasi pada penderita DM sehingga self management penderita meningkat. Self management pada penderita yang mengalami masalah penyakit kronis diakui secara luas sebagai bagian penting dalam perawatan diri dan hal tersebut dapat ditingkankan melalui pemberian edukasi yang tepat. Salah satu program edukasi yang dapat dilakukan adalah berdasarkan program Diabetes Self Management Edukasi (DSME). Melalui pemberian program edukasi berbasis DSME diharapkan penderita DM mampu mencegah komplikasi yang dapat muncul. Selain itu berpartisipasi dalam program pendidikan manajemen diri dapat meningkatkan keterampilan penderita mengelola diabetes secara lebih efektif dengan memeriksa gula darah secara teratur, diet sehat, melakukan aktivitas fisik, minum obat sesuai resep dokter, serta menangani stres akibat diabetes.

\section{REFERENSI}

Black, J. M., \& Hawks, J. H. (2014). Keperawatan medikal bedah: manajemen klinis untuk hasil yang diharapkan edisi 8. Singapura: Elsevier.

CDC. (2018). Managing diabetes. Diperoleh tanggal $26 \quad$ Maret 2019. http://www.cdc.gov.

International Diabetes Federation Atlas (IDF Atlas). (2015). IDF diabetes Atlas $7^{\text {th }}$ ed 2015. Diperoleh tanggal 25 Maret 2019. Diakses dari http://www.idf.org.

Fauzia, H. A., Nugroho, H., \& Margawati, N. (2018). Hubungan antara tingkat pengetahuan dan aspek perilaku dengan status kontrol glikemik pasien diabetes mellitus di RSUP DR. Kariadi. Jurnal Kedokteran Diponegoro, 7 (2). Diperoleh tanggal 26 Mei 2019. Diakses dari http://ejournal3.undip.ac.id/index.php/ medico.

Funnel, M. M., et al. (2012). National standards for diabetes self 
management education. Diabetes Care, 35 (1). Diperoleh tanggal 25 Maret 2019. Diakses dari http://www.diabetesjournals.org.

Karaoui, L. R., et al. (2018). Knowledge and practice of patients with diabetes mellitus in Lebanon: A cross sectional study. BMC Public Health, 18:525. Diperoleh tanggal 26 Mei 2019. Diakses dari https://doi.org/10.1186/s12889-0185416-7.

Muchiri, J. W., Gericke, G. J., \& Rheeder, P. (2016). Impact of nutrition education on diabetes knowledge and attitudes of adults with type 2 diabetes living in a resource-limited setting in South Africa: A randomised controlled trial. Journal of Endocrinology, Metabolism and Diabetes of South Africa, 21 (2), 26-34. Diperoleh tanggal 25 Juni 2019. Diakses dari http://dx.doi.org/10.1080/16089677.20 16. 1200324

Paswan, S. K., et al. (2016). Role of nutrition in the management of diabetes mellitus. Asian Pacific journal Health Sciences 3 (1), 1-6. Diperoleh tanggal 25 Maret 2019. Diakses dari https://pdfs.semanticscholar.org.pdf.

Riskedas (2018). Laporan Nasional Riskesdas 2018. Badan penelitian dan pengembangan kesehatan: Kemenkes RI. Diperoleh tanggal 25 Maret 2019. Diakses dari http://www.litbang.depkes.go.id.

Sami, W., et al. (2017). Effect of diet on type 2 diabetes mellitus: A review. International of Health Science, 11 (2), 65-71. Diperoleh tanggal 26 Maret 2019. Diakses dari https://www.ncbi.nlm.nih.gov/pmc/arti cles/PMC5426415/

Sievenpiper, J. L., et al. (2018). Nutritio therapy: Diabetes Canada clinical practice guidelines expert committee. Canadian Journal of Diabetes, 42 (2018), 564-579. Diperoleh tanggal 01 Juni 2019. Diakses dari https://doi.org/10.1016/j.jcjd.2017.10.0 09.

Shrivastava, S. R., Shrivastava, P. S., \& Romasamy, J. (2013). Role of self care in management diabetes melitus. Journals of Diabetes \& Metabolic Disorders, 12 (14). Diperoleh tanggal 25 Maret 2019. Diakses dari http://wwwncbi.nlm.nih.gov.

Smeltzer, S. C., Bare, B. G., Hinkle, J. L., \& Cheever, K. H. (2010). Brunner \& Suddarth's Textbook of medicalsurgical nursing (12th ed.). Philadelphia, FA: Lippincott Williams \& Wilkins. 